\title{
Dampak Social Dostancing Covid-19 "Himbauan Mudik Siap Huni Rumah Angker di Sragen
}

\section{Safitri Zuliana ${ }^{1}$, Anita Dewi Kurniasari ${ }^{2}$, Markhamah ${ }^{3}$}

s200190006@student.ums.ac.id ${ }^{1}$, anitadewik.ad@gmail.com² ${ }^{2}$,mar274@ums.ac.id ${ }^{3}$

Universitas Muhammadiyah Surakarta, Indonesia

\begin{abstract}
This study has two objectives, the first to describe the effect of Covid-19 social distance for travelers in Sragen, and to describe whether the haunted house provided for independent quarantine for travelers has a deterrent effect. In this study, researchers used a qualitative descriptive design and the techniques used in data collection were listening and note taking techniques. The data source of this study consisted of data obtained from YouTube about social impacts, and the deterrent effect received by the community in the presence of an appeal that had been enforced in Sragen. Data analysis, which is used in this study is a text analysis technique. This technique is a technique used to describe the long-term social impact of covid-19" appeals for homecoming in haunted houses in Sragen". Research results show that the appeal imposed by the Sragen regent has a positive impact on the welfare of the community, with the existence of this community appeal can be enforced regulations that have been imposed with independent isolation for four days at home.
\end{abstract}

Keywords: Covid-19; Social Distancing; Quarantine

\begin{abstract}
Abstrak
Penelitian ini memiliki dua tujuan, yang pertama mendeskripsikan dampak social distancing Covid-19 untuk pemudik di Sragen, dan mendeskripsikan apakah rumah angker yang disediakan untuk karantina mandiri bagi pemudik memiliki efek jera. Pada penelitian ini peneliti menggunakan desain deskriptif kualitatif dan teknik yang digunakan dalam pengumpulan data yaitu teknik simak dan teknik catat. Sumber data penelitian ini berupa data yang diperoleh dari youtobe mengenai dampak sosial, dan efek jera yang dirasakan oleh masyarakat dengan adanya himbauan yang telah diberlakukan di sragen. Analisis data, yang digunakan dalam penelitian ini adalah teknik analisis teks. Teknik tersebut merupakan teknik yang digunakan untuk mendeskripsikan dampak sosial distancing covid-19 "himbauan mudik siap huni rumah angker di sragen". Hasil penelitian menunjukkan bahwa himbauan yang diberlakukan oleh bupati sragen ini memiliki dampak yang positif untuk kesejahteraan masyarakat, dengan adanya himbauan tersebut masyarakat dapat mematuhi peraturan yang sudah diberlakukan dengan isolasi mandiri selama empat belas hari dirumah.
\end{abstract}

Kata kunci: Covid-19; Social Distancing; Karantina.

\begin{tabular}{l|l|l|} 
DOI & $: 10.24903 / k u j k m . v 6 i 2.921$
\end{tabular}

\begin{tabular}{l|l|l|}
\hline Received & $:$ & June 2020 \\
\hline Accepted & $:$ & June 2020 \\
\hline Published & $:$ & December 2020 \\
\hline
\end{tabular}

Copyright Notice

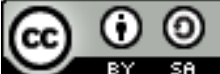

This work is licensed under Creative Commons Attribution 4.0 International License.

P-ISSN: 2477-1880 E-ISSN: 2502-6623

PENDAHULUAN
Beberapa pengamatan terkait

berbagai pandemi yang membahayakan 
dunia. Pengamatan melalui tahapan yang sangat sulit karena melawan yang akan dihadapi adalah sebuah virus yang tak terlihat, virus itu adalah COVID-19 coronavirus (Nadeem, 2020). Corona virus bukanlah suatu wabah yang dapat diabaikan begitu saja, wabah ini bukanlah wabah yang biasa, (Rezki \& Nur, 220:228). Virus ini hadir dengan sangat menyita perhatian, bukan hanya mempengaruhi kesehatan manusia akan tetapi virus ini juga mempengaruhi perekonomian dunia, (Muhammad \& Chairul, 2020:92). Virus ini secara tidak langsung sangat berdampak pada dunia dan memiliki dampak yang signifikan, (Saputra, dkk 2020:5). Virus corona (Covid-19) telah mendorong upaya karantina terbesar yang diketahui di dunia, hampir semua negara didunia termasuk Indonesia melakukan "Lock Down" dalam rangka penanggulangan wabah virus corona (Covid-19) ini. Mengantisipasi dan mengurangi jumlah penderita virus corona di Indonesia sudah dilakukan di seluruh daerah. Diantaranya dengan memberikan kebijakan membatasi aktifitas keluar rumah, kegiatan sekolah dirumahkan, bekerja dari rumah (work from home), bahkan kegiatan beribadah pun dirumahkan. Hal ini sudah menjadi kebijakan pemerintah berdasarkan pertimbangan-pertimbangan yang sudah dianalisa dengan maksimal tentunya (Nur Rohim, 2020).
Terkait aktifitas yang dirumahkan sudah menjadi kebijakan dalam kondisi khusus yang harus dilakukan. Kebijakan ini diharapkan mampu mengatasi masalah yang terjadi di masyarakat. Kebijakan ini ditetapkan oleh beberapa pihak terutama pemerintah yang diorientasikan pada pemenuhan kebutuhan dan kepentingan masyarakat. Makna dari pelaksanaan kebijakan publik merupakan suatu hubungan yang memungkinkan pencapaian tujuan-tujuan atau sasaran sebagai hasil akhir dari kegiatan yang dilakukan pemerintah. Kekurangan atau kesalahan kebijakan publik akan dapat diketahui setelah kebijakan publik tersebut dilaksanakan. Keberhasilan pelaksanaan kebijakan publik dapat dilihat dari dampak yang ditimbulkan sebagai hasil evaluasi atas pelaksanaan suatu kebijakan.

Pelaksanaan metode lockdown dan social distancing dapat menekan laju penyebaran virus seperti yang dialami oleh China dan Korea Selatan. Social Distancing menjauhi perkumpulan, menghindari pertemuan massal, dan menjaga jarak anta manusia (Kosasih, dalam Ericha 2020). Social distancing diterapkan untuk menghambat penyebaran Covid-19, (Windhiyana:2020:4). DI Sragen Karantina mandiri sudah diterapkan dan disosialisasikan kepada masyrakat. Hal ini sejalan dengan yang diungkapkan Risda, 
dkk (2020:7). Tetapi kebijakan ini juga berdampak pada kesejahteraan masyarakat, untuk tahun 2020 ini perantau tidak diizinkan mudik atau pulang ke masingmasing kampung halaman. Meski sudah dijelaskan larangan atau peraturan masih tetap ada beberapa masyarakat yang nekat melanggar perauran itu. Sehingga di Indonesia memiliki cara yang ketat, khususnya di Sragen. Di Sragen memiliki cara tersendiri untuk melakukan karantina mandiri di rumah angker seragen untuk masyarakat yang nekat melanggar larangan mudik. Berharap dengan adanya hukuman tersebut masyarakat lebih jera dan patuh pada larangan mudik tersebut.

Dari penjabaran di atas penelitian ini memiliki dua tujuan, yang pertama mendeskripsikan dampak social distancing Covid-19 untuk pemudik di Sragen, dan mendeskripsikan apakah rumah angker yang disediakan untuk karantina mandiri bagi pemudik memiliki efek jera.

\section{METODE PENELITIAN}

Pada penelitian ini peneliti menggunakan desain deskriptif kualitatif dan teknik yang digunakan dalam pengumpulan data yaitu teknik simak dan teknik catat (Sudaryanto:2015). Sumber data penelitian ini berupa data yang diperoleh dari youtobe mengenai dampak sosial, dan efek jera yang dirasakan oleh masyarakat dengan adanya himbauan yang telah diberlakukan di sragen. Analisis data, yang digunakan dalam penelitian ini adalah teknik analisis teks. Teknik tersebut merupakan teknik yang digunakan untuk mendeskripsikan dampak sosial distancing covid-19 "himbauan mudik siap huni rumah angker di sragen".

\section{HASIL PENELITIAN}

\section{a. Dampak Social Distancing Covid- 19 untuk Pemudik di Sragen}

Dampak sicial distancing Covid-19 untuk pemudik di Sragen tidak dapat melakukan mudik atau pulang kampung. Meski pemudik harus tetap pulang, harus mengikuti peraturan yang sudah disepakati oleh pemerintah Sragen. Bagi pemudik enggan melaksanakan perjanjian untuk karaktina mandiri di rumah angker selama 14 hari, desa bisa mengambil tindakan tegas. Beberapa data yag akan dipaparan terkait dampak social distancing Covid-19 untuk Pemudik di Sragen.

\section{Data 1}

"Bagi pemudik yang tidak bisa ditahan untuk pulang dan harus tetap pulang tidak apa-apa tetapi harus taat aturan. Kalau tidak mau ikut aturan untuk karantina mandiri ya 
masukin ke rumah kosong berhantu saja" (Ujaran Yuni, dari Hops.id: 2020).

Analisis data 1 memaparkan dampak social distancing Covid-19 bahwa perantau tidak diperbolehkan mudik atau pulang ke kampung halaman, bagi sisapapun melanggar akan dihukum sesuai aturan untuk karantina mandiri di rumah kosong berhantu.

\section{Data 2}

"Yang Ari dan Rokhim, tiga hari orangtuanya datang terus minta anaknya dikeluarkan. Mereka ampun ampun dan siap bertanggungjawab menjamin kalau nanti akan isolasi mandiri di rumah. Akhirnya atas kesepakatan Satgas dan warga, mereka dilepas dalam hari yang sama dengan catatan kalau mbandel lagi, langsung dijemput lagi," papar Kades Sepat, Mulyono, dikutip laman popnesia.com : 2020.

Analisis data 2, memaparkan bahwa dampak yang dialami Ari dan Rokhim melakukan isolasi mandiri di rumah kosong berhantu. Karena dari keluarganya terutama orang tuanya tidak tega melihat anaknya berhari-hari tinggal di rumah berhantu, orang tua Ari dan Rokhim memohon ampun pada Satgas dan warga untuk melepaskan anaknya dengan jaminan akan melakukan isolasi mandiri di rumah.

\section{Data 3}

“Corona enggak, mati jantungan iya," tulis seorang warganet di Twitter (Ferdiaz Nikita Yulia, 2020).

Analisis data 3, warga Sragen yang nekat mudik harus melakukan karantina mandiri di rumah kosong berhantu. Dampak yang tejadi untuk pemudik yang nekat akan adanya respon fight or flight yang muncul saat merasa ketakutan akibat makhluk halus merujuk pada reaksi fisiologis yang akan mengakibatkan stres, baik secara mental maupun fisik. Bahkan dapat beresiko penyakit jantung.

\section{Data 4}

"Kalau di persentase kemungkinan ada kenaikan kehamilan di angka 10\%," paparnya Senin (27/4/2020). Ketua Ikatan Penyuluh Keluarga Berencana (IPKB) Sragen Suwanto. joglosemarnews.com Analisis data 4, memaparkan bahwa angka kehamilan meningkat. Dengan adanya social distancing penyuluhan pada pasangan usia subur dan layanan terhadap akseptor tidak bisa berjalan optimal. Sehingga berdampak pada peningkatan kehamilan pada pasangan usia subur.

b. Rumah Angker yang Disediakan untuk Karantina Mandiri bagi Pemudik Memiliki Efek Jera Bagi Mayarakat. 
Hasil menunjukan bahwa karantina mandiri yang dihuni tiga warga sragen memiliki efek jera bagi penghuninya. Karantina mandiri yang disampaikan oleh Dani \& Mediantara (2020:100) bahwa karantina merupakan sebuah upaya untuk membatasi pergerakan dari populasi yang beresiko. Karantina yang disampaikan Dani \& Mediantara digunakan oleh bupati sragen untuk memberikan efek jera kepada masyarakat yang bandel. Rumah angker yang disediakan dihuni oleh tiga penghuni yang tidak patuh terhadap peraturan, sehingga mereka harus menempati rumah angker yang sudah disediakan untuk karantina mandiri. Hal ini dibuktikan oleh beberapa berita yang disampaikan di beberapa chanel youtobe:

\section{Data 5}

"Alhasil dua pemudik pun ketakutan dan kapok setelah dua hari berturut turut menanggis ditempat ini, mereka pun meminta dispensasi untuk menjalani karantina mandiri di kediaman masingmasing" (SCTV)

Menurut data 6 juga menyatakan hal serupa bahwa pemudik yang ditempatkan di rumah angker tersebut kapok dan meminta dispensasi untuk menjalani karantina mandiri dirumah masing-masing

\section{Data 6}

"Enakan dirumah kalau saya, masalahnya kan bisa liat anak, istri, kalau disini kan temennya cuman setan nggk ada kegiatan, pokoknya galau lah, kurang nyaman tempatnya agak angker masalahnya" (TV One)

Begitu juga dengan data 7 menyampaikan bahwa pemudik yang ditempatkan dirumah angker tersebut merasa tidak nyaman dengan suasana tempat karantina yang angker.

\section{Data 7}

"Disini ya ikut aturan sini saya, saya menyesal, dan bukan untuk kebaikan saya saja masyarakat, dan keluarga. paling cuman video call dengan anak" (Indosiar)

Berita itu juga dipertegas oleh lurah desa spat mulyono mengatakan ada 3 pemudik bandel yang tidak menaati karantina mandiri.

\section{Data 8}

"Sudah tiga orang yang pertama masuk tanggal enam belas, yang kedua masuk tanggal delapan belas dua orang, dari Kalimantan, lampung, Jakarta" (Trans TV Official)

\section{Data 9}

"Menurut pihak desa rumah karantina tersebut memang sudah lama tidak di huni orang sehingga memiliki kesan angker bagi 
warga sekitar" Kartika bagus menyampaikan berita yang telah diperoleh. (Trans TV Official)

Berita yang disampaikan dari beberapa chanel youtobe diatas dapat disimpulkan bahwa rumah angker yang digunakan untuk karantina mandiri itu memiliki efek jera bagi penghuninya. Mereka kapok dan berjanji akan mematuhi peraturan yang ada setalah merasakan beberapa hari berada dirumah tersebut. efek jera yang sudah dirasakan bagi pemudik bandel ini dapat menjadi himbauan bagi masyarakat lain agar tidak melanggar peraturan yang sudah ada.

\section{KESIMPULAN}

Dampak himbauan yang diberlakukan oleh bupati sragen ini memiliki dampak yang positif untuk kesejahteraan masyarakat, dengan adanya himbauan tersebut masyarakat dapat mematuhi peraturan yang sudah diberlakukan dengan isolasi mandiri selama empat belas hari dirumah. Mereka merasa takut jika harus karantina dirumah angker. Kepatuhan yang dilakukan masyarakat memiliki dampak bagi kesejahteraan dalam menciptakan suasana lingkungan yang aman dan kondusif.

\section{REFERENSI}

Dani.J.A., \& Mediantara, Y. (2020). Covid19 dan Perubahan Komunikasi Sosial. Jurnal Persepsi. 3(1).94102.

Ferdiaz, Nikita Yulia. (2020, 26 April). Viral Rumah Angker Dijadikan Tempat Karantina Pemudik di Sragen, Warganet Malah Berseloroh Soal Makhluk Halus: Corona enggak Mati Jantungan Iya. Dikutip 28 Mei 2020 dari:https://health.grid.id/read/3521 23070/viral-rumah-angkerdijadikan-tempat- karantinapemudik-di-sragen-warganetmalah-berseloroh-soal-makhlukhalus-corona-enggak-matijantungan-iya?page $=$ all

Muhammad \& Chairul. (2020). Ancaman Krisis Ekonomi Global dari Dampak Penyebaran Virus Corona (Covid-19). Jurnal Akmen. 17(1). 90-98.

Nadeem, S. (2020). Coronavirus COVID19: Available Free Literature Provided By Various Companies, Journals and Organizations Around the Literature Provided By Various Companies, Journals and Organizations Around the World. March. 
https://doi.org/10.5281/zenodo.372

2904

Pratiwi, Ericha Windhiyana. 2020. Dampak Covid-19 di Sebuah Perguruan Tinggi Kristen di Indonesia. Prerspektif Ilmu Pendidikan, Vol. 34, No.1

Popnesia, Portol. (2020, 26 April). Isolasi Mandiri di Rumah Angker, Pemudik Bnadel di Sragen Nangisnangis Minta Keluar. Dikutip 28 Mei 2020 dari Isolasi Mandiri di Rumah Angker, Pemudik Bnadel di Srage Nangis-nangis Minta Keluar: https://www.popnesia.com/2020/04 /isolasi-mandiri-di-rumahangker-pemudik.html

Rezki dan Nur. (2020). Kebijakan Pemberlakuan Lockdown sebagai Antisipasi Penyebaran

Corona Virus Covid-19. Jurnal Salam. 7(3). 227-238.

Risda, dkk. (2020). Penggunaan Bahan Herbal dan Pendekatan Spiritual untuk mencegah Stress Selama Karantina Covid-19. Jurnal Diglib. 2(1). 1-12.

Saputra, dkk (2020). Industri Microstock sebagai Peluang Peningkatan Ekonomi Kreatif di
Tengah Pandemi Covid-19. Jurnal Amikom. 1(1). 1-12.

Sudaryanto. 2015. Metode dan Aneka Teknik Analisis Bahasa: Pengantar Penelitian Wahana

Kebudayaan Secara Linguistis. Yogyakarta.

Widiarini, Anisa. (2020, 21 April). Bupati Sragen Ancam Pemudik Bandel, Bakal Karantina di Rumah Angker. Dikutip 28 Mei 2020 dari Bupati Sragen Ancam Pemudik Bandel, Bakal Karantina di Rumah Angker: https://www.hops.id/bupati-sragenancam-pemudik-bandel-bakalkarantina- di-rumah-angker/

Windhiyana. E. (2020). Dampak Covid-19 terhadap kegiatan pembelajaran online di sebuah perguruan tinggi kristen di Indonesia. Jurnal Perspektif Ilmu Pendidikan. 34(1). 1-8.

Wardoyo, Puspo. (2020, 27 April). Dampak Anjuran Lockdown dan Diam di Rumah, Jumalh Ibu Hamil di Sragen Diprediksi Naik 10\%. Petugas Penyuluhan KB Akui Kesulitan Jalankan Penyuluhan, Jumlah Akseptor Menurun 45\%. Dikutip 28 Mei 2020 dari: https://joglosemarnews.com/2020/ 
04/dampak- anjuran-lockdown-

dan-diam-di-rumah-jumlah-ibu-

hamil-di-sragen-diprediksi- naik-

10-petugas-penyuluh-kb-akui-

kesulitan-jalankan-penyuluhan-

jumlah-akseptor-menurun-45/

Yunus, Nur Rohim dan Annisa Rezki.

2020. Kebijakan Pemberlakuan

Lockdown Sebagai Antisipasi

Penyebaran Corona Virus Covid-

19. Salam: Jurnal Sosial

\&Budaya Syar-i, Vol.7(3): 227-

238. 